Journal of the Operations Research

Society of Japan

Vol.21, No.2, June, 1978

\title{
AN ADJACENT PAIRWISE APPROACH TO THE MEAN FLOW-TIME SCHEDULING PROBLEM.
}

\author{
Shigeji Miyazaki, Noriyuki Nishiyama and Fumio Hashimoto \\ University of Osaka Prefecture
}

(Received Decernber 10, 1977; Revised February 22, 1978)

\begin{abstract}
In this paper, sufficient conditions to decide the precedence relation between neighboring two jobs are presented by means of an adjacent pairwise interchage method for minimizing mean flow-time in flow-shop scheduling. On the bases of the sufficient conditions, a computational algorithm is proposed for an optimal or near optimal solution. The mean flow-time by this algorithm puts $90 \%$ of the optimal value as an average of over one hundred problems. The algorithm can be executed even by manual calculations within the time proportional to $n \times m^{2}$, where $n$ and $m$ are the number of jobs and machines respectively.
\end{abstract}

\section{Introduction}

Ever so much research [1 $\sim 9]$ has been devoted to flow-shop scheduling, yet relatively few results exist for performance measures other than maximal flow-time. For instance, Nabeshima [5] presented an algorithm based on the sufficient conditions to minimize maximal flow-time in flow-shop scheduling where no passing is allowed. The same approach, however, has not been applied to the mean flow-time problem, which is as significant a performance measure as the maximal flow-time.

In this paper, the sufficient conditions are given to decide the precedence relation between neighboring two jobs to minimize the mean flow-time in flow-shop scheduling problem. An algorithm based on the sufficient conditions is also presented for an optimal or near optimal solution.

The computational experience shows that the approximation ratio between obtained solutions and the optimal ones indicates $90 \%$ as an average of over one hundred problems. Moreover, it shows that the algorithm can be executed even by manual calculations within the time proportional to (the number of jobs) $\times(\text { the number of machines })^{2}$. 
2. Definition of the Mode1

The discussed model can be defined as follows:

1) Let $n$ be the number of jobs to be processed, and $i$ th job in an arbitrary sequence $S$ is denoted by $J_{i}$ where $i=1,2, \cdots, n$. All these jobs are available for processing at time zero.

2) The manufacturing system consists of $m$ different machines which are numbered according to the order of production stage. Let $M_{j}$ be the $j$ th machine in the system where $j=1,2, \cdots, m$. Every machine is continuously available.

3) Every job is completed through the same production stage that is $M_{1} \rightarrow$ $M_{2} \rightarrow, \cdots, \rightarrow M_{m}$.

4) Let $p_{i, j}$ denote the processing time of $J_{i}$ on $M_{j}$. Setup times for operations are sequence-independent and are included in processing times. Handling times are assumed to be so limited that they can be neglected.

5) The same job sequence occurs on each machine; in other words, no passing is allowed in the shop.

6) The other conditions on usual flow-shop problem are also assumed.

3. Formulation of Mean Flow-.Time

Let $T_{j}(i)$ denote the partial flow-time of $J_{i}$ counted from the completion

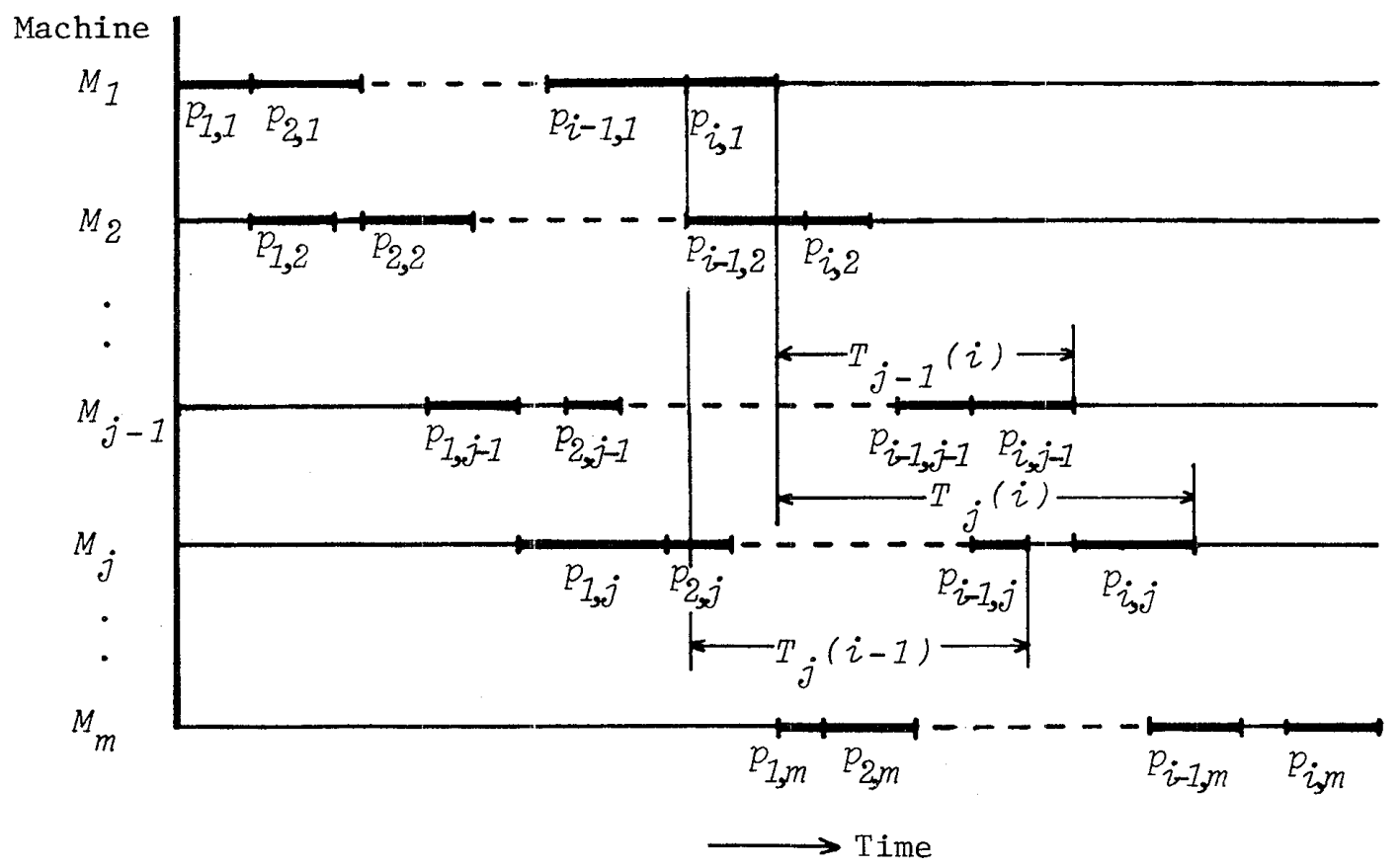

Fig. 1 Definition of $T_{j}(i)$ 
time of $J_{i}$ on $M_{1}$ to that of $J_{i}$ on $M_{j}$, referring to Fig. 1 . There exist recurrence relations $(3.1)$ on $T_{j}(i)$, because the starting time of $J_{i}$ on $M_{j}$ should not be earlier than both the completion time of $J_{i}$ on $M_{j-1}$ and the completion time of $J_{i-1}$ on $M_{j}$.

$$
T_{j}(i)=p_{i, j}+\max \left\{T_{j}(i-1)-p_{i, 1}, T_{j-1}(i)\right\}, i=1,2, \cdots, n ; j=2,3, \cdots m,
$$

where $T_{j}(0) \equiv 0, T_{1}(i) \equiv 0$.

Let $F_{i}$ be the flow-time of $J_{i}$, that is, the whole elapsed time of $J_{i}$ counted from the starting time of $J_{1}$ on $M_{1}$, to the completion time of $\mathrm{J}_{i}$ on $M_{m}$. Then $F_{i}$ is given by:

$$
F_{i}=\sum_{t=1}^{i} p_{t, 1}+T_{m}(i), \quad i=1,2, \cdots, n \text {. }
$$

Mean flow-time $\bar{F}$ for $n$ different jobs processed on $m$ machines is:

$$
\bar{F}=\frac{1}{n} \sum_{i=1}^{n} F_{i}=\frac{1}{n} \sum_{i=1}^{n}\left\{\sum_{t=1}^{i} p_{t, 1}+T_{m}(i)\right\}
$$

Therefore we have, from (3.3),

$$
n \bar{F}=\sum_{i=1}^{n} F_{i}=\sum_{i=1}^{n}\left\{\sum_{t=1}^{i} p_{t, 1}+T_{m}(i)\right\},
$$

where $n \bar{F}$ expresses the total flow-time of $n$ jobs, $n \bar{F}$ sha11 be used in place of $\bar{F}$ in the further analysis, since $n$ is a constant independent of a sequence.

In the sequence $S$, let $s$ be a subsequence consisting of the first $q-1$ jobs, that is, $J_{1}, J_{2}, \cdots, J_{q-1}$, and in succession to $s, J_{q}$ and $J_{q+1}$ ( these two jobs are called adjacent two jobs hereafter) are assumed to be processed in the order $J_{q} J_{q+1}$. Now consider the sequence $S^{\prime}$ in which $J_{q}$ and $J_{q+1}$ are pairwise interchanged and are processed in the order $J_{q+1} J_{q}$. The sequence is the same for the first $q-1$ jobs and the last $(n-q-1)$ jobs under either $S$ or $S^{\prime}$ as illustrated in Fig. 2 .

In order to distinguish the notation of partial flow-time under $S$ from $S$, let $T_{m}(q), T_{m}(q, q+1)$, and $T_{m}(i){ }_{S}(i=q+2, q+3, \cdots, n)$ denote the partial flowtime of $J_{q}, J_{q+1}$, and $J_{i}(i=q+2, q+3, \cdots, n)$ under $S$ in turn, and let $T_{m}(q+1)$, $T_{m}(q+1, q)$, and $T_{m}(i) S^{-}(i=q+2, q+3, \cdots, n)$ denote the partial flow-time of $J_{q+1}$, $J_{q}$, and $J_{i}(i=q+2, q+3, \cdots, n)$ under $S^{-}$in turn, moreover let $\bar{F}^{\prime}$ be the mean flow-time under $S^{\prime}$. Then the total flow-time under $S$ and $S^{\prime}$ are formulized by (3.5) and (3.6) respectively, of which terms are divided into four parts that 


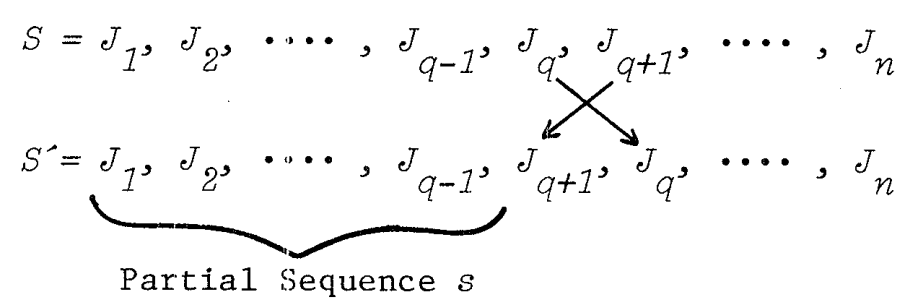

Fig. 2 Sequence $S$ and $S^{\prime}$.

are the summation of the flow-times over all jobs belonging to $s$, the flowtime of $J_{q}$, the flow-time of $J_{q+1}$, and the summation of the flow-times over al1 jobs following $J_{q+1}$.

$$
\begin{gathered}
n \bar{F}=\sum_{i=1}^{q-1}\left\{\sum_{t=1}^{i} p_{t, 1}+T_{m}(i)\right\}+\sum_{t=1}^{q-1} p_{t, 1}+p_{q, 1}+T_{m}(q)+\sum_{t=1}^{q+1} p_{t, 1} \\
\quad+T_{m}(q, q+1)+\sum_{i=q+2}^{n}\left\{\sum_{t=1}^{i} p_{t, 1}+T_{m}(i){ }_{S}\right\} .
\end{gathered}
$$

$$
\begin{gathered}
n \bar{F}^{\prime}=\sum_{i=1}^{q-1}\left\{\sum_{t=1}^{i} p_{t, 1}+T_{m}(i)\right\}+\sum_{t=1}^{q-1} p_{t, 1}+p_{q+1,1}+T_{m}(q+1)+\sum_{t=1}^{q+1} p_{t, 1} \\
+T_{m}(q+1, q)+\sum_{i=q+2}^{n}\left\{\sum_{t=1}^{i} p_{t, 1}+T_{m}(i)_{S^{-}}\right\} .
\end{gathered}
$$

Eliminating the common terms between (3.5) and (3.6) from the each equation, and denoting the remaining, $\langle n \bar{F}\rangle$ and $\left\langle n \bar{F}^{-}\right\rangle$, respectively, we have:

$$
\langle n F\rangle=p_{q, 1}+T_{m}^{T}(q)+T_{m}(q, q+1)+\sum_{i=q+2}^{n} T_{m}(i)_{S}
$$

and

$$
\left\langle n \bar{F}^{\prime}\right\rangle=p_{q+1,1}+T_{m}(q+1)+T_{m}(q+1, q)+\sum_{i=q+2}^{n} T_{m}(i) S^{\prime} \cdot
$$

4. The Order of Adjacent Two Jobs

If,

$$
\langle n \bar{F}\rangle \leqq\left\langle n \bar{F}^{-}\right\rangle
$$

that is:

$$
n \bar{F} \leqq n \bar{F}^{\prime}
$$


holds, $J_{q+1}$ cannot directly precede $J_{q}$ in the optimal sequence, because (3.7) and (3.8) exist independent of adjacent two jobs position in a sequence. Either of $J_{q}$ and $J_{q+1}$ can optimally precede the other, provided there exists equality in (4.1). Therefore, we shall investigate the sufficient conditions to satisfy (4.1) in the following:

Comparing each term of (3.7) with the corresponding term of (3.8), we have:

$$
\begin{aligned}
p_{q, 1}+T_{m}(q) & \leqq p_{q+1,1}+T_{m}(q+1), \\
T_{m}(q, q+1) & \leqq T_{m}(q+1, q),
\end{aligned}
$$

and

$$
\sum_{i=q+2}^{n} T_{m}(i) \leq \sum_{i=q+2}^{n} T_{m}(i) S^{-}
$$

which are to be sufficient conditions of (4.1).

$T_{m}(q)$ and $T_{m}(q+1)$ in $(4.3)$ are, from (3.1), given by:

$$
T_{m}(q)=p_{q, m}+\max \left\{T_{m}(q-1)-p_{q, 1}, T_{m-1}(q)\right\}
$$

and

$(4.7)$

$$
T_{m}(q+1)=p_{q+1, m}+\max \left\{T_{m}(q-1)-p_{q+1,1}, T_{m-1}(q+1)\right\}
$$

Working out recurrence relations $(4.6)$ and $(4.7)$, we have:

$$
T_{m}(q)=\max _{r=1 \sim m}\left\{T_{m-r+1}(q-1)+\sum_{t=1}^{r} p_{q, m-t+1}\right\}-p_{q, 1}
$$

and

$(4.9)$

$$
T_{m}(q+1)=\max _{r=1 \sim m}\left\{T_{m-r+1}(q-1)+\sum_{t=1}^{r} p_{q+1, m-t+1}\right\}-p_{q+1,1} .
$$

Substituted into $(4.3),(4.8)$ and (4.9) give

$$
\text { (4.10) } \max _{r=1 \eta m}\left\{T_{m-r+1}(q-1)+\sum_{t=1}^{r} p_{q, m-t+1}\right\} \leqq \max _{r=1 r m}\left\{T_{m-r+1}(q-1)+\sum_{t=1}^{r} p_{q+1, m-t+1}\right\} \text {. }
$$

Since $T_{m-r+1}(q-1)$ is common between both sides of (4.10), the comparison between each relative term of $(4.10)$ gives the next $m$ different inequalities:

$$
\sum_{t=1}^{r} p_{q, m-t+1} \leq \sum_{t=1}^{r} p_{q+1}, m-t+1, \quad(r=1,2, \cdots, m),
$$


which are to be sufficient conditions of (4.10) that is equivalent to (4.3), as completely proved at the following theorem.

Now, we shall investigate the sufficient conditions of (4.4) and (4.5).

The partal flow-time of $J_{q+2}$ under $S$ is given as similar to (4.8),

$$
T_{j}(q+2)_{S}=\max _{r=1 v_{j}}\left\{T_{j-r+1}(q, q+1)+\sum_{t=1}^{r} p_{q+2, j-t+1}\right\}-p_{q+2,1}
$$

which is the nondecreasing function of each $j$ terms $T_{k}(q, q+1)(k=1,2, \cdots, j)$.

The partial flow-time of $J_{q+2}$ under $S^{-}$is also given as similar to (4.9),

$$
T_{j}(q+2)_{S^{\prime}}=\max _{r=1 \nu_{j}}\left\{T_{j-r+1}(q+1, q)+\sum_{t=1}^{r} p_{q+2, j-t+1}\right\}-p_{q+2,1}
$$

which is the nondecreasing function of each $j$ terms $T_{k}(q+1, q)(k=1,2, \cdots, j)$. So that, if:

$$
T_{j}(q, q+1) \leq T_{j}(q+1, q), \quad(j=1,2, \cdots, m),
$$

then

$$
T_{j}(q+2)_{S} \leq T_{j}(q+2)_{S^{-}}, \quad(j=1,2, \cdots, m)
$$

Moreover, under (4.15), $T_{j}(q+3)_{S} \leqq T_{j}(q+3)_{S}$, holds for every $j(j=1,2, \cdots, m)$ from (3.1), and similar inequalities as (4.15) hold for $J_{q+4}, \cdots, J_{n}$ in turn.

Therefore, (4.14) should be sufficient conditions of (4.5), by the reason that (4.5) is concerned with the summations of the partial flow-time of $J_{q+2}$, $J_{q+3}, \cdots, J_{n}$ on $M_{m}$. Inequality $(4.4)$ is contained in $(4.14)$, since $(4.14)$ in the case of $j=m$ corresponds to $(4.4)$.

Nabeshima [5] proved that the next $m(m-1) / 2$ inequalities:

$$
\text { (4.16) } \quad \min \left(p_{q, j}, p_{q+1, j+1}\right) \leqq \min \left(p_{q+1, j}, p_{q, j+1}\right), \quad(j=1,2, \cdots, m-1) \text {, }
$$

and

(4.17) $\min \left(\sum_{j=u}^{v} p_{q, j}, \sum_{j=u+1}^{v+1} p_{q+1, j}\right) \leqq \min \left(\sum_{j=u}^{v} p_{q+1, j}, \sum_{j=u+1}^{v+1} p_{q, j}\right),(1 \leqq u<v \leq m-1)$

are the sufficient conditions of (4.14).

The discussion above should lead to the following theorem:

Theorem. If $m(m+1) / 2$ inequalities:

$$
\sum_{t=1}^{r} p_{q, m-t+1} \leqq \sum_{t=1}^{r} p_{q+1, m-t+1}, \quad(r=1,2, \cdots, m),
$$


(4.16) $\min \left(p_{q, j}, p_{q+1, j+1}\right) \leqq \min \left(p_{q+1, j}, p_{q, j+1}\right),(j=1,2, \cdots, m-1)$, and

(4.17) $\min \left(\sum_{j=u}^{v} p_{q, j}, \sum_{j=u+1}^{v+1} p_{q+1, j}\right) \leqq \min \left(\sum_{j=u}^{v} p_{q+1, j}, \sum_{j=u+1}^{v+1} p_{q, j}\right),(1 \leq u<v \leq m-1)$, hold, then $J_{q+1}$ cannot directly precede $J_{q}$ to minimize the mean-flow time in flow-shop scheduling where no passing is allowed. If equality signs hold in all of (4.11), (4.16), and (4.17), each of $J_{q}$ and $J_{q+1}$ may directly precede the other.

Proof: The demonstration here may be restricted to the statement that (4.11) is sufficient condition of (4.3) for any number of machines $m$ over two, since Nabeshima [5] has proved that (4.16) and (4.17) are the sufficient conditions of (4.4) and (4.5). The theorem can be demonstrated by mathematical induction as follows:

Inequality $(4.3)$ for $m=2$ is

$$
p_{q, 1}+T_{2}(q) \leq p_{q+1,1}+T_{2}(q+1)
$$

which is, from(3.1), rewritten by :

$$
\begin{aligned}
\max \left\{T_{2}(q-1)\right. & \left.+p_{q, 2}, T_{1}(q-1)+p_{q, 2}+p_{q, 1}\right\} \\
& \leq \max \left\{T_{2}(q-1)+p_{q+1,2}, T_{1}(q-1)+p_{q+1,2}+p_{q+1,1}\right\} .
\end{aligned}
$$

Sufficient conditions of (4.18) are simply given by:

$$
p_{q, 2} \leqq p_{q+1,2}
$$

and

$$
p_{q, 2}+p_{q, 1} \leqq p_{q+1,2}+p_{q+1,1}
$$

These inequalities coincide with (4.11) for $m=2$, consequently (4.11) should be the sufficient conditions of (4.3) for $m=2$.

Now suppose that (4.11) is the sufficient condition of (4.3) for $m=K$, where $K$ is an arbitrary integer greater or equal than 2 . This assumption may be rewritten by the following statement that

$$
\sum_{t=1}^{r} p_{q, K-t+1} \leqq \sum_{t=1}^{r} p_{q+1}, K-t+1,(r=1,2, \cdots, K)
$$

are the sufficient conditions of

$$
p_{q, 1}+I_{K}(q) \leqq p_{q+1,1}+T_{K}(q+1) .
$$


For $m=K+1$, the partial flow-time under $S$ and $S^{\prime}, T_{K+1}(q)$ and $T_{K+1}(q+1)$, are given as established in (3.1):

$$
T_{K+1}(q)=p_{q, K+1}+\max \left\{T_{K+1}(q-1)-p_{q, 1}, T_{K}(q)\right\},
$$

and

$$
T_{K+1}(q+1)=p_{q+1, K+1}+\max \left\{T_{K+1}(q-1)-p_{q+1,1}, T_{K}(q+1)\right\}
$$

Therefore, each side of (4.3) for $m=K+1$ is respectively:

$$
p_{q, 1}+T_{K+1}(q)=\max \left\{p_{q, K+1}+T_{K+1}(q-1), p_{q, 1}+p_{q, K+1}+T_{K}(q)\right\},
$$

and

$$
p_{q+1,1}+T_{K+1}(q+1)=\max \left\{p_{q+1, K+1}+T_{K+1}(q-1), p_{q+1,1}+p_{q+1, K+1}+T_{K}(q+1)\right\}
$$

From (4.23) and (4.24), the sufficient conditions of

$$
p_{q, 1}+T_{K+1}(q) \leqq p_{q+1,1}+T_{K+1}(q+1)
$$

should be given by:

$$
p_{q, K+1} \leqq p_{q+1, K+1}
$$

and

$$
p_{q, 1}+p_{q, K+1}+T_{K}(q) \leqq p_{q+1,1}+p_{q+1, K+1}+T_{K}(q+1) .
$$

Since, from the preliminary assumption for $m=K$, the sufficient conditions of

$$
p_{q, 1}+T_{K}(q) \leqq p_{q+1,1}+T_{K}(q+1)
$$

are (4.19), and each side of $(4.20)$ is the first and third term of corresponding side of (4.26), so that:

$$
\sum_{t=1}^{r} p_{q, K-t+1}+p_{q, K+1} \leq \sum_{t=1}^{r} p_{q+1, K-t+1}+p_{q+1, K+1}, \quad(r=1,2, \cdots, K) .
$$

should be the sufficient conditions of $(4.26)$.

Rearranging (4.25) and (4.27), we have

$$
\sum_{t=1}^{r} p_{q, K-t+2} \leqq \sum_{t=1}^{r} p_{q+1, K-t+2}, \quad(r=1,2, \cdots, K+1) .
$$


These inequalities (4.28) coincide with (4.11) for $m=K+1$. Therefore, (4.11) should be sufficient condition of (4.3) for $m=K+1$, under the assumption that (4.11) is the sufficient condition of (4.3) for $m=K$.

These statements above prove that (4.11) is the sufficient condition of (4.3) for any integer $m$ greater or equal than 2.

5. Algorithm

We now propose an algorithm to find an optimal or near optimal solution that minimizes the mean flow-time using above theorem, since the theorem holds for any positions of the adjacent two jobs in the sequence. The algorithm will be explained by solving an example problem composed of four jobs and four machines. The processing times of each operation in the example are listed in Table 1 .

Step 1. Decide $m$ kinds of temporary sequences which can lead from (4.11) as follows: compile a table of which the first, second and last mth row value correspond to $p_{i, m}, p_{i, m}+p_{i, m-1}$, and $p_{i, m}+\cdots+p_{i, 1}$ in turn, as tabulated in Table 2. Make $m$ kinds of temporary sequences consisting of $n$ jobs in accordance with the nondecreasing order of each row value in Table 2. Assign an integer between 1 and $n$ to each

Table 1. Processing Times. Table 2. Sum of Processing Times.

\begin{tabular}{c|c|cccc}
\hline$j$ & $P_{i, j}$ & $J_{1}$ & $J_{2}$ & $J_{3}$ & $J_{4}$ \\
\hline 1 & $p_{i, 1}$ & 5 & 5 & 3 & 6 \\
\hline 2 & $P_{i, 2}$ & 7 & 6 & 5 & 5 \\
\hline 3 & $p_{i, 3}$ & 3 & 5 & 5 & 7 \\
\hline 4 & $P_{i, 4}$ & 4 & 3 & 6 & 5 \\
\hline
\end{tabular}

\begin{tabular}{l|c|rrrr}
\hline$r$ & $\sum p_{i, j}$ & $J_{1}$ & $J_{2}$ & $J_{3}$ & $J_{4}$ \\
\hline 1 & $p_{i, 4}$ & 4 & 3 & 6 & 5 \\
\hline 2 & $p_{i, 4}+p_{i, 3}$ & 7 & 8 & 11 & 12 \\
\hline 3 & $p_{i, 4}+\cdots+p_{i, 2}$ & 14 & 14 & 16 & 17 \\
\hline 4 & $p_{i, 4}+\cdots+p_{i, 1}$ & 19 & 19 & 19 & 23 \\
\hline
\end{tabular}

Table 3. Ordinal Numbers by Step 1 .

\begin{tabular}{l|rrrr}
\hline$r$ & $J_{1}$ & $J_{2}$ & $J_{3}$ & $J_{4}$ \\
\hline 1 & 2 & 1 & 4 & 3 \\
\hline 2 & 1 & 2 & 3 & 4 \\
\hline 3 & 1 & 1 & 3 & 4 \\
\hline 4 & 1 & 1 & 1 & 4 \\
\hline
\end{tabular}

Table 4. Ordinal Numbers by Step 2 .

\begin{tabular}{l|llll}
\hline$j$ & $J_{1}$ & $J_{2}$ & $J_{3}$ & $J_{4}$ \\
\hline 1 & 2 & 2 & 1 & 4 \\
\hline 2 & 4 & 3 & 1 & 1 \\
\hline 3 & 1 & 4 & 2 & 3 \\
\hline
\end{tabular}

Table 5. Ordinal Numbers by Step 3 .

\begin{tabular}{l|l|lrrr}
\hline$U$ & $v$ & $J_{1}$ & $J_{2}$ & $J_{3}$ & $J_{4}$ \\
\hline & 2 & 4 & 2 & 1 & 2 \\
\cline { 2 - 6 } 1 & 3 & 4 & 3 & 1 & 2 \\
\hline 2 & 3 & 3 & 3 & 1 & 2 \\
\hline
\end{tabular}


job according to its ordinal number in the temporary sequence as shown in Table 3. In case more than two jobs have the same value in a row, assign the same integers to them. An example of this can be seen in the third and fourth rows of Table 3.

Step 2. Make $m-1$ kinds of temporary sequences, in terms of applying Johnson's Rule [4] to (4.16) for each value of $j=1,2, \cdots, m-1$. Assign an integer between 1 and $n$ to each job according to its ordinal number in this temporary sequence as shown in Table 4. Assign the same integers to the jobs which can occupy the same position in the temporary sequence by this step.

Step 3. Apply Johnson's Rule to (4.17), regarding the serial machines from $M_{u}$ to $M_{v}$ as the first machine and the serial machines from $M_{u+1}$ to $M_{v+1}$ as the second machine. Total number of temporary sequences made by this step becomes $(m-1)(m-2) / 2$ which coincides with the total number of combinations between $u$ and $v$ under the restrictions on their range shown in (4.17). Assign an integer between 1 and $n$ to each job according to its ordinal number in this temporary sequence as shown in Table 5 .

Step 4. Calculate the sum of integers Table 6. Sum of Ordinal Numbers. assigned to each job in the step 1,2 , and 3 as shown in Table 6 . Arrange each job in the nondecreasing order of the total inte-

\begin{tabular}{c|cccc}
\hline Job & $J_{1}$ & $J_{2}$ & $J_{3}$ & $J_{4}$ \\
\hline $\begin{array}{l}\text { Sum of Ordi- } \\
\text { na1 Numbers }\end{array}$ & 23 & 22 & 18 & 29 \\
\hline
\end{tabular}
gers. Break a tie by placing jobs with lower original numbers first.

The solution for this example becomes $J_{3}-J_{2}-J_{1}-J_{4}$, which is the optimum. In case all of the temporary sequences are equal, the solution inevitably becomes the optimum.

\section{Efficiency of the Algorithm}

In order to verify the efficiency of the algorithm, 16 examples tabulated in Table 7 were solved. Obtained solutions were appraised by the approximation ratio defined by (6.1), and the results are summarized in Table 8 .

$$
\eta=100 \times(w-\alpha) /(w-0)
$$

Where $\eta$ is the approximation ratio, $w, a$, and 0 are the maximal (worst), the obtained, and the optimal value of performance measure respectively. The 
Table 7. Solved Flow-Shop Problems.

\begin{tabular}{|c|c|c|c|c|c|c|}
\hline$m^{n}$ & 3 & 4 & 5 & 6 & & \multirow{5}{*}{$\begin{array}{l}\text { Standard deviation } \\
\text { of processing times } \\
\text { (Uniform random in- } \\
\text { tegers with mean } 5 \text { ) } \\
P_{1}=0.8, P_{2}=1.4, \\
P_{3}=2.0, P_{4}=2.6 .\end{array}$} \\
\hline 3 & $P_{1}$ & $P_{2}$ & $P_{3}$ & $P_{4}$ & & \\
\hline 4 & $P_{2}$ & $P_{1}$ & $P_{4}$ & $P_{3}$ & & \\
\hline 5 & $P_{3}$ & $P_{4}$ & $P_{2}$ & $P_{1}$ & & \\
\hline 6 & $P_{4}$ & $P_{3}$ & $P_{1}$ & $P_{2}$ & & \\
\hline
\end{tabular}

Table 9. The Results of Analysis of Variance, $\mathrm{F}(3,6: 0.05)=4.76$.

\begin{tabular}{c|cccc}
\hline Factor & $S$ & $\Phi$ & $V$ & $F_{O}$ \\
\hline$n$ & 375.4 & 3 & 125.1 & 3.58 \\
\hline$m$ & 188.5 & 3 & 62.8 & 1.80 \\
\hline$P$ & 331.4 & 3 & 110.5 & 3.17 \\
\hline$E$ & 209.5 & 6 & 34.9 & \\
\hline Sum & 1104.8 & 15 & & \\
\hline
\end{tabular}

Table 8. Approximation Ratio.

\begin{tabular}{r|cccc}
\hline$m$ & 3 & 4 & 5 & 6 \\
\hline 3 & 83.3 & 92.9 & 81.8 & 84.8 \\
\hline 4 & 100.0 & 85.7 & 96.6 & 98.4 \\
\hline 5 & 100.0 & 98.5 & 79.3 & 89.7 \\
\hline 6 & 100.0 & 88.2 & 73.3 & 97.9 \\
\hline
\end{tabular}

Table 10. The Required Times for Solutions by Hand.

\begin{tabular}{c|cccc}
\hline$m$ & 3 & 4 & 5 & 6 \\
\hline 3 & 1.5 & 3.5 & 4 & 5 \\
\hline 4 & 6 & 7 & 7.5 & 11.5 \\
\hline 5 & 9 & 9.3 & 12.5 & 18 \\
\hline 6 & 9 & 15 & 19.5 & 24 \\
\hline
\end{tabular}

approxomation ratio defined by (6.1) contains the maximal and the optimal value of performance measure so as to reach $0 \%$ in case the obtained solution coincides with the maximal one, and $100 \%$ in case the obtained solution coincides with the optimal one.

The average of ratios in Table 8 is $90.7 \%$ and the analysis of variance shown in Table 9 indicates that none of the three factors, the number of jobs, the number of machines, and the standard deviation of processing times affect the approximation ratio.

Another 90 different examples which have 2 to 6 jobs and 2 to 6 machines were solved, having shown $90.2 \%$ for the average approximation ratio. The algorithm may be executed even by hand calculations which need the time proportional to $n \times m^{2}$, since the time is subject to the number of jobs and the number of inequalities. Table 10 is an example of the executed time by manual calculations.

The step 4 of the proposed algorithm can be replaced by the similar procedure as the step 2, 3, and 4 in Nabeshima's. Although the replaced algorithm may generate as high an approximation ratio as the proposed one, it takes two or three times as long to ececute the replaced one than to execute the original one. 
7. Conclusions

The summary of the results is as follows:

1) The sufficient conditions were presented to minimize mean flow-time in flow-shop scheduling where no passing is allowed. It was proved by mathematical induction that the conditions should exist for any number of machines.

2) The algorithm based on the sufficient conditions is proposed for an optimal or near optimal solution.

3) More than one hundred examples were solved by the algorithm, having shown $90 \%$ for the approximation ratio on an average. None of the three factors, the number of jobs, the number of machines, and the standard deviation of processing times affected the value of approximation ratio.

4) The algorithm may be executed even by hand calculations which need the time proportional to $n \times m^{2}$.

\section{Acknowledgement}

The authors wish to thank Mr. Hirao Fujikawa for his help in deriving the equations and in achieving the numerical examples throughout this study.

\section{References}

[1] Gupta, J. N. D.: Optimal. Flowshop Scheduling with Due Dates and Pena1ty Costs. Joumal of the Operations Research Society of Japan, Vo1. 14, No. 3(1971), 35-46.

[2] Gupta, J. N. D.: Heuristic Algorithms for Multistage Flowshop Scheduling Problem. AIIE Transactions, Vol. 4, No. 1(1972), 11-18.

[3] Igna11, E. and Schrage, L.: Application of the Branch and Bound Technique to Some Flow-Shop Scheduling Problems. Operations Research, Vo1. 13, No. 3(1965), 400-412.

[4] Johnson, S. M.: Optimal Two- and Three-Stage Production Schedules with Setup Times Included. Naval Research Logistics Quarterly, Vo1. 1, No. 1 (1954), 61-68.

[5] Nabeshima, I.: The Order of $n$ Items Processed on $m$ Machines [III]. Journal of the Operations Research Society of Japan, Vo1. 16, No. 3(1973), 163-185.

[6] Panwa1kar, S. S. and Khan, A. W.: An Ordered Flow-Shop Sequencing Problem with Mean Completion Time Criterion. Intemational Joumal of Production Research, Vo1. 14, No.5(1976), 631-635. 
[7] Smith, M. L., Panwalkar, S. S. and Dudek, R. A.: Flow-Shop Sequencing Problem with Ordered Processing Time Matrices: A General Case. Naval Research Logistics Quarterly, Vol. 23, No. 3(1976), 481-486.

[8] Szwarc. W.: Optimal Elimination Methods in the $m \times n$ Flow-Shop Scheduling Problem. Operations Research, Vo1. 21, No. 6(1973), 1250-1259.

[9] Yueh Ming-I : On the $n$ Job, $m$ Machine Sequencing Problem of Flow-Shop. OR'75 : Proceedings of the Seventh International Conference on Operational Research (ed. K. B. Haley). North-Holland Publishing Company, Amsterdam, 1976, 179-200.

Shigeji MIYAZAKI: Department of Industrial Engineering, College of Engineering, University of Osaka Prefecture, Mozu-UmeMachi, Sakai, Osaka, 591, Japan. 


\title{
アブストラクト
}

\section{隣接 2 ショゴ交換法による平均滞留時間スケジュ-リング問題の解}

\author{
大阪府立大学 宮 崎 茂 次 \\ 西山徳幸 \\ 橋 本 文 雄
}

鍋島は， 1973 年にショブ数・㙨械台数が任意のフロー・ショップ・スケシューリング問題で, 最大滞留時間を最小にする十分条件式を導出した。また，得られた十分条件式に基づいて近似アルゴ リズムを提案し，ある種の近似率を用いてそのアルゴリズムの有効性を検証した。しかし、鍋島と同 様の問題で，平均滞留時間を最小亿する解析は行われていない。平均滞留時間は，各ショブの加工完 了時刻の平均值であり，仕掛在庫量と密接に関係する評価尺度である。平均滞留時間に関する研究に は，Panwalkar らや，Gupta などの研究がある。前者は，最適解を求めることのできる特殊な条 件をもつ問題を取り扱っているだけで，一般の問題に適用できるアルゴリズムは提出していない。後 者は，いわゆる発見的解法であり，解析的な取り扱いによる解を与えていない。

そこで本研究では，ショブ数・機械台数が任意の追抜禁止フロー・ショップ・スケシューリング問 題を取りあげ，平均滞留時間を最小沉する十分条件式を導出する。得られた十分条件式に基づいて， 最適解または準最適解を得るためのアルゴリズムを提案する。用いる手法は，Johnson，鍋島など も使用している隣接 2 ショブ交換法である。この手法は，隣接する 2 ショブの先行関係を決定する推 移性をむつ条件式を導き，それ基づくアルゴリズムを得ようとするものである。

さらに，求めた解の質を評価するために，新しい近似率の定義式を導入する。従来使用されていた 近似率は，単佂最適解と近似解の值の比率で求めていた。したかっって。近似解が最悪解と一致した場 合であ，ある程度高い近似率が得られるなどの不合理な点もあった。そこで，可能解の範囲（最適解 と最悪解の市）を考慮した近似率を新しく定義して使用する。この近似率は，求めた解が最適解と一 致すれば $100 \%$ ，最悪解と一致すれば $0 \%$ の值になる。

得られた十分条件式は，加工時間の值だけからなる不等式群で構成され，その総数は機械台数の 2 乗にほぼ等しい。すべての不等式は，ショブに関する推移性を满足するので，数ステップからなる比 較的簡単な近似アルゴリズムが提案できる。提案したアルゴリズムを用いて約 100 種の例題を解い た結果, 平均 $90 \%$ の近似率をもつ解が得られた。ショブ数, 機械台数, 加工時間のばらつきなどは, 調査した範囲では近似率に影響を与えなかった。

このアルゴリズムは，簡単な記入用紙による手計算であ遂行できる。解を得るまでに必要な時間は， ショブ数 $\times$ (機械台数) 2 にほほ比例する。たとえば, ショブ数 5 , 機械台数 5 の問題では, 手計算 
で12〜13 分, コンピュータで 0.16 秒の所要時間である。フロ-・ショップ間題は，機械台数 がショブの工程数に等しいため，機械台数の増加には生産技術的に一定の限界が存在する。また本ア ルゴリズムの計算時間は，かなり多くなる可能性のあるショブ数には，単なる一次の比例関係にとど まっている。以上の結果より，提案したアルゴリズムは，実用上効果を発揮すると思われる。 